\title{
COMPARISION OF HPLC AND BIOASSAY METHODS FOR ANALYSIS OF SULFOSULFORUN RESIDUES IN WHEAT FIELD SOIL
}

\author{
KAZEMI, A. ${ }^{*}-$ HOODAJI, M. \\ Department of soil science, College of Agriculture, Isfahan (Khorasgan) Branch, \\ Islamic Azad University, Isfahan, Iran \\ (phone: +98-31-35354045; fax: +98-31-35354045) \\ *Corresponding author \\ e-mail: kazemi_alireza_ak@yahoo.com; phone: +98-31-32370119 \\ (Received $13^{\text {th }}$ Dec 2016; accepted $24^{\text {th }}$ Mar 2017)
}

\begin{abstract}
Sulfosulfuron, a new sulfonylurea herbicide, is used to control certain broadleaf and grass weed species in wheat fields. Herbicides, when applied to the field may leave unwanted residues in the soil. Bioassay and chemical assay techniques are main methods for monitoring herbicides levels in agricultural soils. Thus, a set of field and greenhouse experiments was established to evaluate the reliability and accuracy of HPLC and bioassay techniques to detect sulfosulfuron residues in the soil of the wheat field. The experiment was conducted in a randomized complete block design with three treatments in three replications for each treatment in 2014-2015 and 2015-2016 growing seasons at Marvdasht location. Herbicide treatments included: sulfosulfuron (apirus) at 26.6 and $53.2 \mathrm{~g}$ a.i. $\mathrm{ha}^{-1}$ rates and no-herbicide control. Herbicide was sprayed at the end of tillering stage of wheat in a field experiment. Samples were collected randomly with an auger from 0-10 cm depth at different times i.e. 0, 3, 10, 20, 30, 60, 90 and 125 days after herbicide spray. The bioassay experiment showed that root parameter was more sensitive to sulfosulfuron as compared with the shoot. According to the results, among the studied plants, garden cress was recognized as the most sensitive plant to different rates of sulfosulfuron herbicide. At recommended (26.6 g a.i. ha-1) and double $\left(53.2 \mathrm{~g}\right.$ a.i. $\left.\mathrm{ha}^{-1}\right)$ rates of application sulfosulfuron residues were detected up to 60 and 90 days after treatment by HPLC and bioassay techniques in both years, respectively. According to the bioassay and HPLC techniques at two rates of application, residues decreased with time in 2014 and 2015.
\end{abstract}

Keywords: herbicide, bioassay, high-performance liquid chromatography, half-life, root parameter

\section{Introduction}

Most farming systems extensively use herbicides. When applied to the field, herbicides control targeted weeds and leave unwanted residues in the soil that are harmful ecologically (Haney et al., 2000; Derksen et al., 2002). Despite the great efficacy of herbicide for controlling weeds, its residual effect should be taken into account for the safety of the environment. Ideal herbicides should have good efficacy and minimum adverse effects on crops, ecology and the environment (Faheed and AbdElfattah, 2007).

The most important crop in Iran is wheat which can be considered as the main food for the entire population (Vahedi-Sheikhhasan et al., 2012; Rahman et al., 2008). The second crops such as cotton, corn, soybean, canola and sunflower are sown after wheat is harvested as rotation crops. Good weed control is a necessary component of wheat yield (Hasanuzzaman et al., 2009). To do this, in wheat fields, the application of herbicides especially sulfonylurea is common. In the 1970s, sulfonylurea herbicides were introduced, which are a class of herbicides that were used as control chemicals for the majority of broad-leaved weeds and common grasses in agriculture (Coly and 
Aaron, 1999; Guibiao et al., 2006). These herbicides reside in the acetolactate synthase enzyme which is the main enzyme in the biosynthesis of branched-chain amino acids and is characterized by a high herbicidal activity that leads to application at low rates (Nystrom and Blanck, 1998; Brown, 1990; Ye et al., 2003). Sulfonylurea herbicides apply post-emergence in cereal specially wheat therefore there was short period between herbicide application and next planting which caused adverse effects on crops in rotation with wheat (Menne and Berger, 2001). Of sulfonylurea herbicides, sulfosulfuron (1- (4,6-Dimethoxypyrimidin-2-yl) -3- (2-ethylsulfonylimidazol [1,2-a] pyridin-3-ylsulfonyl) urea), has been suggested for weed control in wheat fields (Nurse et al., 2007). Sulfosulfuron which is a new sulfonylurea herbicide, is used to control weeds in different agricultural crops and wheat (Parrish et al., 1995). These new herbicides have an extensive range of soil residual characteristics that must help with meeting specific agricultural requirements (Maheshwari and Ramesh, 2007). Sulfonylurea herbicides consist of 3 distinct parts: a sulfonylurea bridge, an aryl group and an S-triazine group. Of the reasons they were quickly accepted include a very low animal toxicity, low application rate and a broad-spectrum weed control. The removal of sulfonylurea herbicides can be done in three ways in the environment and these methods are: chemical hydrolysis, microbial degradation and photodegradation. Potential transformation in sulfonylurease is the cleavage of the sulfonylurea bridge yielding sulfonamide, S-triazine and Striazinurea bridge contraction and ring opening which forms triurets (Sarmah et al., 1998).

Soil $\mathrm{pH}$, organic matter, moisture and temperature are the major factors that affect sulfonylurea chemical hydrolysis and microbial degradation. In soil, sulfonylurea hydrolysis is primarily $\mathrm{pH}$ dependent and its rate goes up with decreasing soil $\mathrm{pH}$ (Beyer et al., 1988). Recent studies have proven a similar $\mathrm{pH}$ dependence of sulfosulfuron hydrolysis in soil incubation research (Saha and Kulshrestha, 2002). The study of Pusino et al. (2003) which was done on the desorption and the adsorption of a sulfonylurea herbicide triasulfuron in three different soils, revealed that, $\mathrm{pH}$ was the main cause which affected the absorption level and also showed that, adsorption in soils, was negatively correlated with $\mathrm{pH}$. The highest amount of adsorption was measured in soils which had low $\mathrm{pH}$ and high organic carbon content. In specific conditions like highly alkaline soils with low temperatures and organic matter contents in dry regions, sulfonylurea herbicides might persist at phytotoxic rates in soils to have negative impacts on sensitive crops in the subsequent season (Stork, 1995).

The main methods for monitoring herbicide levels in agricultural soils are Bioassay and Chemical assay techniques such as high performance liquid chromatography (HPLC) and gas chromatography (GC) (Tchan et al., 1975; Johnson et al., 2005; Watson and Checkel, 2005). Because the application of chemical techniques was limited due to higher costs, the bioassay technique is a useful tool to detect residues herbicides. Moreover, chemical assay techniques are able to determine herbicide residues rates but cannot determine that these rates are really toxic to plants (Szmigielski et al., 2008). Alonso-Prados et al. (2002) showed that the European Commission Guidance Document on Residue Analytical Methods has accepted and suggested bioassays as suitable screening tests that can be good for excluding the occurrence of low levels of residues of phytotoxic compounds in soils. Many researchers used bioassay methods to discover herbicide residues in soil (Alonso-Prados et al., 2002; Blacklow and Pheloung, 1991; Gunther et al., 1993; Hernandez-Sevillano, 2001; Stork and Hannah, 1996). 
The chemical extraction method cannot distinguish between available and unavailable herbicide. Also, a chemical extraction will not show an indication of potential plant response. As a replacement to chemical extraction methods, bioassay is the most accurate method available for the detection and quantification of sulfonylurea residues in soil (Beyer et al., 1988). Based on the study of Ferris and Haigh (1992), bioassay is the level of a plant's response to the total herbicide residue in the soil at a site-specific location.

As far as we know, little or no research has been done to detect sulfosulfuron residues in the soil. The objectives of this research were to: 1) determine half-life of sulfosulfuron in soil, 2) determine the most sensitive plant species to sulfosulfuron, 3) and to compare analytical and bioassay techniques for monitoring sulfosulfuron herbicide level in soil.

\section{Material and Methods}

\section{Field Experiment}

The study were conducted in two consecutive years 2014-2015 and 2015-2016 at Marvdasht location (Fars province, Iran) that situated in 29 52'43.46" N (Latitude DMS) and 52 49'13.99" E (Longitude DMS) (Fig. 1). Before sowing, soil samples were taken from 0 to $30 \mathrm{~cm}$ depth and physicochemical properties of the experimental site were determined (Table 1). The field at the test site had lain fallow the year before the start of our study. To prepare the seedbed, deep plowing $(20-25 \mathrm{~cm})$ with a moldboard plough were carried each year in autumn, followed by disking in the spring. The soil fertility was increased by using diammonium phosphate (18-46-0 N-P-K) and urea at the rate of 250 and $150 \mathrm{~kg}$ a.i. $\mathrm{ha}^{-1}$, respectively, each year in spring before planting. Moreover, $200 \mathrm{~kg}$ a.i. ha ${ }^{-1} \mathrm{~N}$ (as urea) was added at the 6-8 leaf growing stage of wheat along with irrigation. The wheat hybrid "Singles Cross 704" was sown at desired density (7 plants a.i. $\mathrm{m}^{-2}$ ), seeds spaced $18.5 \mathrm{~cm}$ apart in rows spaced $20 \mathrm{~cm}$ apart on 15 May 2014 and 22 May 2015. The experimental design at two years was a randomized complete block with three replications. Sulfosulfuron was applied as POST (Postemergence application) at $26.6 \mathrm{~g}$ a.i. $\mathrm{ha}^{-1}$ (recommended rate) and $53.2 \mathrm{~g}$ a.i. $\mathrm{ha}^{-1}$ (double rate) with a knapsack sprayer using flat fan nozzle at four-leaf stage in each year. Three plots were sprayed with water without any herbicide and considered as the control plots. The experimental fields were 9 plots $10 \mathrm{~m} \times 3 \mathrm{~m}$ size with a buffer of $0.5 \mathrm{~m}$ between adjacent plots to avoid spray overlap.

Table 1. Physicochemical traits of soil in the location of experiment

\begin{tabular}{|c|c|c|c|c|c|c|c|c|c|c|}
\hline $\begin{array}{c}\text { Soil } \\
\text { texture }\end{array}$ & $\begin{array}{c}\text { Sand } \\
(\%)\end{array}$ & $\begin{array}{l}\text { Silt } \\
(\%)\end{array}$ & $\begin{array}{l}\text { Clay } \\
(\%)\end{array}$ & $\begin{array}{l}N \\
(\%)\end{array}$ & $\begin{array}{c}\mathbf{P} \\
(\mathbf{p p m})\end{array}$ & $\underset{(\mathbf{p p m})}{\mathbf{K}}$ & $\begin{array}{c}\mathrm{CaCO}_{3} \\
(\%)\end{array}$ & $\begin{array}{l}\text { OM } \\
(\%)\end{array}$ & pH & $\begin{array}{c}\mathrm{EC} \\
\left(\mathrm{dS} \mathrm{\textrm {m } ^ { - 1 }}\right)\end{array}$ \\
\hline Clayloam & 34.6 & 35.0 & 30.4 & 0.015 & 3.4 & 240.0 & 12.0 & 0.36 & 7.5 & 0.45 \\
\hline
\end{tabular}



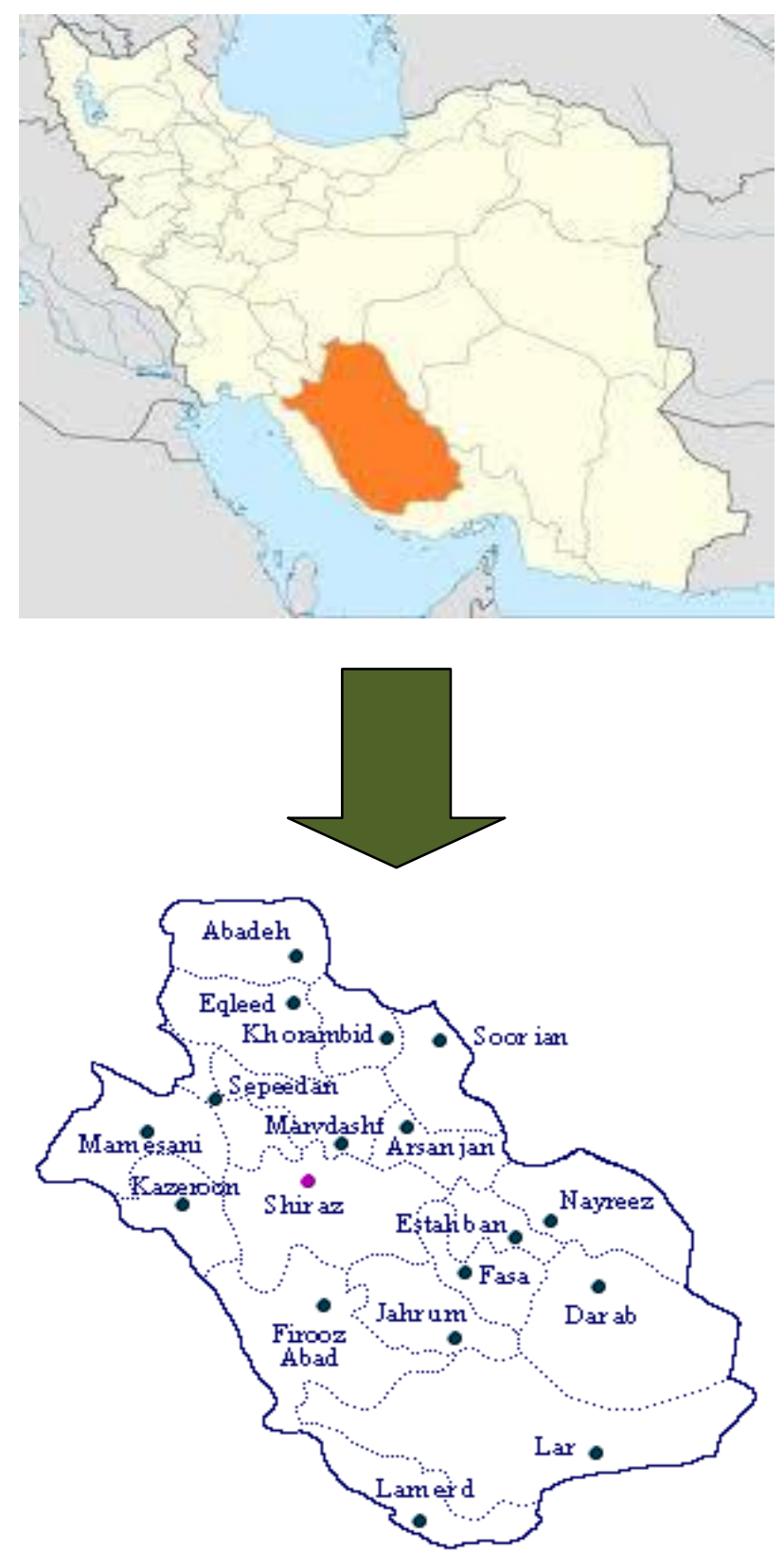

Figure 1. Location of Marvdasht in Fars province

\section{Sampling and Storage}

Soil samples were collected randomly throughout each plot from $0-10 \mathrm{~cm}$ depth using a tube auger $0(2 \mathrm{~h}), 3,10,20,30,60,90$ and 125 days after treatment. Samples were air dried and ground to pass through a 2-mm sieve, mixed thoroughly and subsamples were taken from each plot for the bioassay and HPLC studies. Samples were kept in a deep freezer at $-20{ }^{\circ} \mathrm{C}$ until they were subjected to the bioassay and HPLC analysis. 


\section{Greenhouse Experiment}

\section{Bioassay Technique}

Determination of test plant for bioassay study: Greenhouse experiments were conducted to select the most sensitive plant species to evaluate sulfosulfuron residues in soil. Eight different plant species including lentil (Lens culinaris Medik.), garden cress (Lepidium sativum L.), mung bean (Vigna radiata L.), cucumber (Cucumis sativus L.), corn (Zea mays L.), sugar beet (Beta vulgaris L.), canola (Brassica rapa L.) and chick pea (Cicer arietinum L.) were screened by measuring their shoot and root responses to soil-incorporated. The pots $(10 \mathrm{cmID} \times 10 \mathrm{~cm}$ length) were filled with $500 \mathrm{~g}$ of soil and treated with sulfosulfuron at 5, 10, 20, 50, 75 and $100 \%$ of recommended rate $(26.6 \mathrm{~g}$ a.i. $\mathrm{ha}^{-1}$ ), five pre-germinated seeds of each test-plant were planted at $2-3 \mathrm{~mm}$ depth in each pot. The pots were arranged on greenhouse in a completely randomized design with four replicates along with untreated control pots. The pots were sub-irrigated as needed during the experiment. The plants were uprooted to measure the sulfosulfuron effects on plants root and shoot length at 15 days after planting (Paul et al., 2009). During the experiment, temperature and relative humidity were fluctuated between $18-$ $25^{\circ} \mathrm{C}$ and $58-85 \%$, respectively.

Preparation of standard curve by bioassay and analysis of field samples: To establish a standard curve, the samples soils $(500 \mathrm{~g})$ fortified with sulfosulfuron concentration $(5$, $10,20,50,75$ and $100 \%$ of recommended rate $\left(26.6 \mathrm{~g}\right.$ a.i. $\left.\mathrm{ha}^{-1}\right)$ were filled in the plastic pots with four replicates along with untreated controls. Five pre-germinated garden cress seeds (Lepidium sativum L.) were sown as the indicator species in each pot. The experiment was conducted under greenhouse conditions as completely randomized design. The pots were irrigated as needed to retain the soil moisture. 15 days after sowing, all plants were uprooted and washed carefully with water to remove the soil. Then, root length for garden cress plants were measured as sensitive parameter and the percentage reduction in root length relative to the control plants was calculated for each concentration. A standard curve was drawn by plotting the percentage root inhibition on a vertical linear (y) axis versus the corresponding sulfosulfuron concentration on horizontal logarithmic (x) axis. The soil samples which were taken at different intervals from wheat field were placed in pots, and five pregerminated garden cress seeds were planted into these pots as described above. After 15 days, all plants were uprooted and percentage root inhibition was calculated for each interval. Finally, the herbicide residues were determined under field conditions by fitting the data correspond to percentage root inhibition into the regression equation (Paul et al., 2009).

\section{HPLC Technique}

\section{Chemicals}

Analytical-grade sulfosulfuron (97\% purity) with chromatographically (TLC and HPLC) pure was supplied by Sigma-Aldrich (Steinheim, Germany). The chemical structure of sulfosulfuron herbicide is given in Figure 2. All solvents, such as acetonitril and dichloromethane were HPLC grade and purchased from Merck (Darmstadt, Germany). 


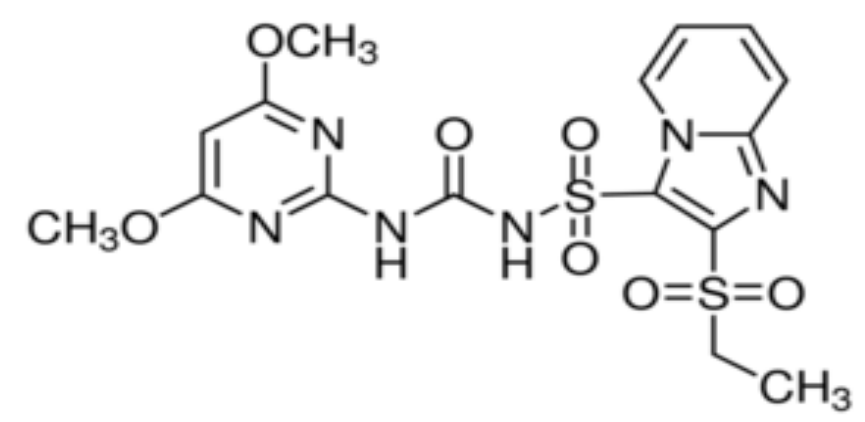

Figure 2. The structure of sulfosulfuron herbicide (1-(4,6-Dimethoxypyrimidin-2-yl)-3-(2ethylsulfonylimidazol[1,2-a]pyridin-3-ylsulfonyl)urea)

\section{Soil Extraction and Clean-up}

Fifty g of soil were put in a conical flask and $50 \mathrm{ml}$ of acetonitrile and ammonium carbonate $(9: 1 \mathrm{v} / \mathrm{v})$ was added to it. The filled flask was shaken for $30 \mathrm{~min}$ and its contents were partitioned. We separated and filtered the upper organic layer. The soil was shaken with $50 \mathrm{ml}$ of acetonitrile: ammonium-carbonate $(9: 1 \mathrm{v} / \mathrm{v})$ once again. next, the upper organic phase were separated and mixed with the first fraction. The mixed extract was gathered and dried at $40^{\circ} \mathrm{C}$ on a rotary evaporator and then decreased to 20 $\mathrm{ml}$. Next, it was dissolved in $50 \mathrm{ml}$ of saline water $(1 \mathrm{M} \mathrm{NaCl})$. The solution was put in the separating funnel and partitioned twice with $50 \mathrm{ml}$ of dichloromethane. The mixed dichloromethane extract was then collected and passed through anhydrous sodium sulfate which was packed in a $30 \mathrm{~cm}$ column to remove all traces of moisture. Then filtrate was collected, pooled and almost completely dried at $40{ }^{\circ} \mathrm{C}$ on a flash evaporator. At the end, the residue was dissolved in $2 \mathrm{ml}$ of HPLC grade acetonitrile and filtered through $0.45 \mu \mathrm{m}$ Millipore system before being injected into the HPLC system (Saha et al, 2003).

\section{Preparation of Standard Curve by HPLC}

A stock solution $\left(1000 \mu \mathrm{g}\right.$ a.i. $\left.\mathrm{mL}^{-1}\right)$ of sulfosulfuron was prepared in acetonitrile and different concentrations including $0.01,0.05,0.1,0.5,1.0,5.0$ and $10.0 \mu \mathrm{g}$ a.i. $\mathrm{mL}^{-1}$ ) of sulfosulfuron were made by diluting the stock solution. A volume of $15 \mu \mathrm{L}$ of each standard solution was injected into the HPLC and the peak area measured. Each run was repeated twice and the calibration curve was created by drawing the known concentrations of sulfosulfuron on the $\mathrm{x}$-axis and the average peak area corresponding to each concentration on the y-axis.

\section{Apparatus Conditions}

Sulfosulfuron was detected with a HPLC equipped with a photodiode array detector, a C18 column ( $250 \mathrm{~mm} \times 4 \mathrm{~mm}$ ID), a mobile phase of acidic water + acetonitrile $+\mathrm{o}-$ phosphoric acid, $20+80+0.1(\mathrm{v} / \mathrm{v})$, a flow rate of $1 \mathrm{~mL}$ a.i. $\mathrm{min}^{-1}$, a UV - detector set at a wavelength of $225 \mathrm{~nm}$. A volume of injection was $15 \mu \mathrm{L}$ for each standard solution and the retention time was $2.9 \mathrm{~min}$. Samples were filtered before injection by a $0.45 \mu \mathrm{m}$ membrane using a millipore filtration syringe. 


\section{Data Analysis}

Data analysis was performed by using the Statistical Analysis System (SAS). Means were compared by the least significant difference (LSD) test at $\alpha=0.05$. The threeparameter sigmoidal model was used to determine dissipation time (DT50) of sulfosulfuron herbicide in Marvdasht location: $\mathrm{f}=\mathrm{a} /\left(1+\exp \left(-\left(\mathrm{x}-\mathrm{x}_{0}\right) / \mathrm{b}\right)\right.$, where the parameter $\mathrm{a}$ is maximum dissipation of herbicide, $\mathrm{b}$ is the slope of the curve around the $\mathrm{X}_{0}$ and $\mathrm{X}_{0}$ donates time required for $50 \%$ dissipation. Figures were drawn by using the microsoft excel software.

\section{Results}

\section{Determination of Test Plant for Bioassay Study}

The bioassay experiment showed that root parameter was more sensitive to sulfosulfuron as compared with shoot. As shown in Figures 3 and 4, the percentage root length reduction was within the approximate range of 40 to $71 \%$ for the bioassay plants, while the shoot length inhibition for bioassay crops was lower (25 to 60\%). Since the roots are directly exposed to the herbicide residues, it seems that the influence of the herbicide residues on roots is higher than shoots. These results revealed the differential sensitivities of plant species to sulfosulfuron. Among the eight crops tested, garden cress had the maximum percentage decrease in root length with root length inhibition of approximately $71 \%$ at recommended rate which was followed by lentil, canola, sugar beet, cucumber, mung bean, chick pea and corn (Fig. 3). Thus, garden cress was considered as the test species for planting in the field soil samples in bioassay experiments and the percentage root length inhibition was found as the standard parameter. This finding is consistent with findings of Paul et al. (2009). Szmigielski et al. (2009) developed the sugar beet bioassay to study the soil-incorporated sulfentrazone.

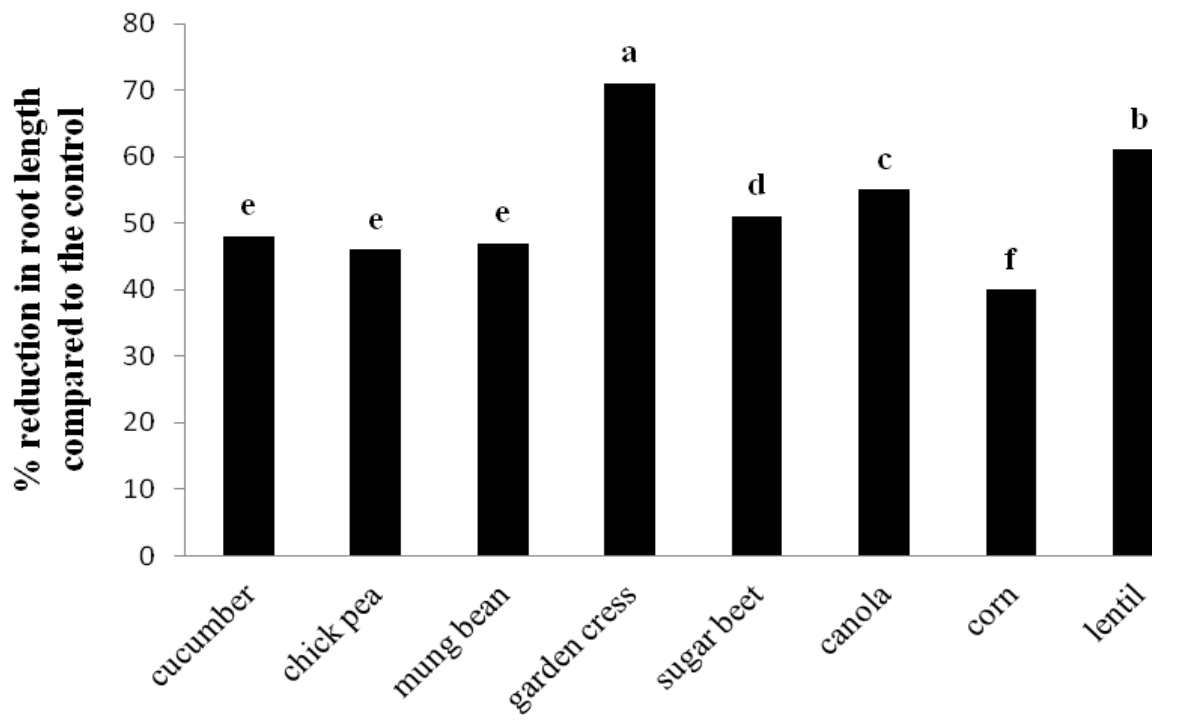

\section{bioassay plants}

Figure 3. Effect of recommended rate of sulfosulfuron on root length in different bioassay plants 


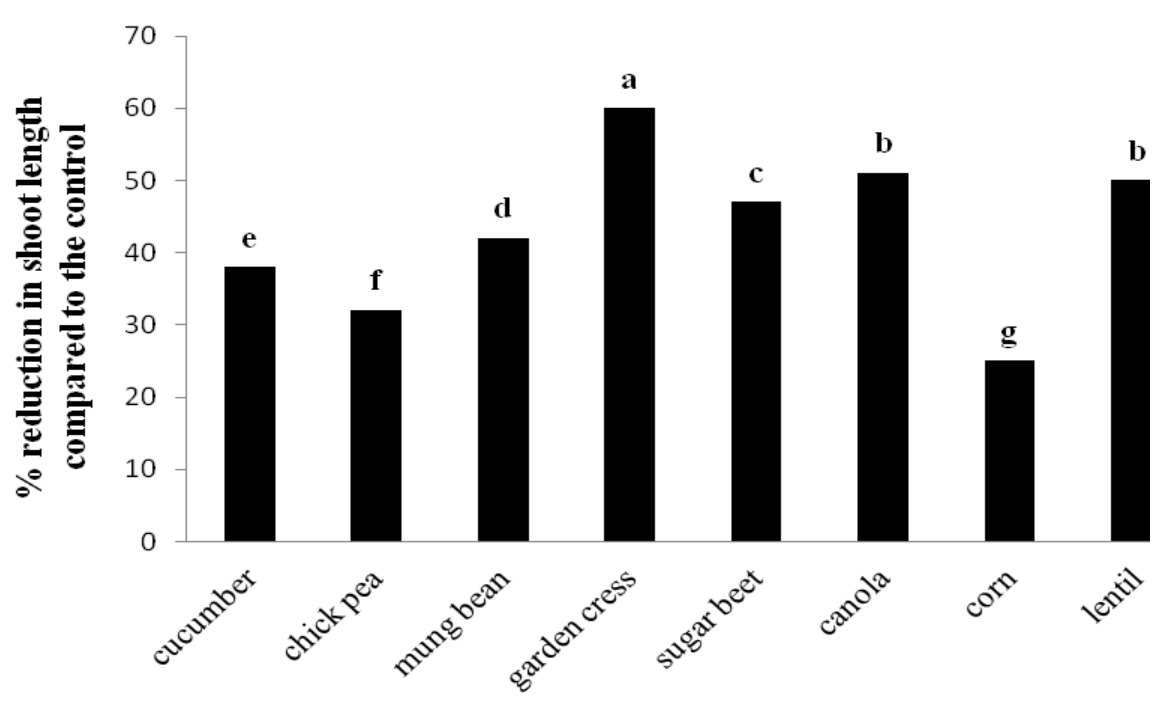

bioassay plants

Figure 4. Effect of recommended rate of sulfosulfuron on shoot length in different bioassay plants

\section{Calibration Curve}

To establish a standard curve, soil samples treated with six different levels of sulfosulfuron $(5,10,20,50,75$ and $\% 100$ of recommended rate) were filled in pots with four replicates for each concentration and five pregerminated garden cress seeds (in each pot) were planted as the indicator species. After 15 days of planting, the percentage reduction in root length of garden cress plants versus different concentrations of sulfosulfuron was measured and the respective calibration curve was drawn. At the recommended rate of application $\left(26.6 \mathrm{~g}\right.$ a.i. $\left.\mathrm{ha}^{-1}\right)$, the best regression equation fitted was linear as $\mathrm{Y}=7.3781 \mathrm{X}+4.0174$ with $\mathrm{R}^{2}=0.97$ (Fig. 5). At the double rate of application (53.2 $\mathrm{g}$ a.i. $\mathrm{ha}^{-1}$ ), the best regression equation fitted was linear as $\mathrm{Y}=4.4272 \mathrm{X}+13.494$ with $\mathrm{R}^{2}=0.98$ (Fig. 6). 15 days after planting, the percentage inhibition of garden cress root length of the field samples, were entered into the standard equation to determine the herbicide concentration that was bioavailable.

For HPLC, a series of standard solutions containing different concentrations of sulfosulfuron $\left(0.01,0.05,0.1,0.5,1.0,5.0\right.$ and $10.0 \mu \mathrm{g}$ a.i. $\left.\mathrm{mL}^{-1}\right)$ were prepared in acetonitrile by diluting the stock solution $\left(1000 \mu \mathrm{g}\right.$ a.i. $\left.\mathrm{mL}^{-1}\right) .15$ microliters of each concentration was injected and the calibration curve was established based on the sulfosulfuron concentration versus corresponding peak. The best fitted regression equation was $\mathrm{Y}=177947 \mathrm{X}+40771$ with $\mathrm{R}^{2}=0.99$.

\section{Recovery and Limit of Quantification (LOQ)}

The accuracy and precision of the method was performed by recovery study. Recovery study was conducted for soil by extraction and analysis of five replicates at three different levels $\left(0.01,0.05\right.$ and $0.1 \mathrm{mg}$ a.i. $\left.\mathrm{kg}^{-1}\right)$. The average recoveries of sulfosulfuron in soil were varied from 78 to $85 \%$. The limit of quantification of sulfosulfuron was detected to be $1 \mu \mathrm{g}$ a.i. $\mathrm{kg}^{-1}$. 


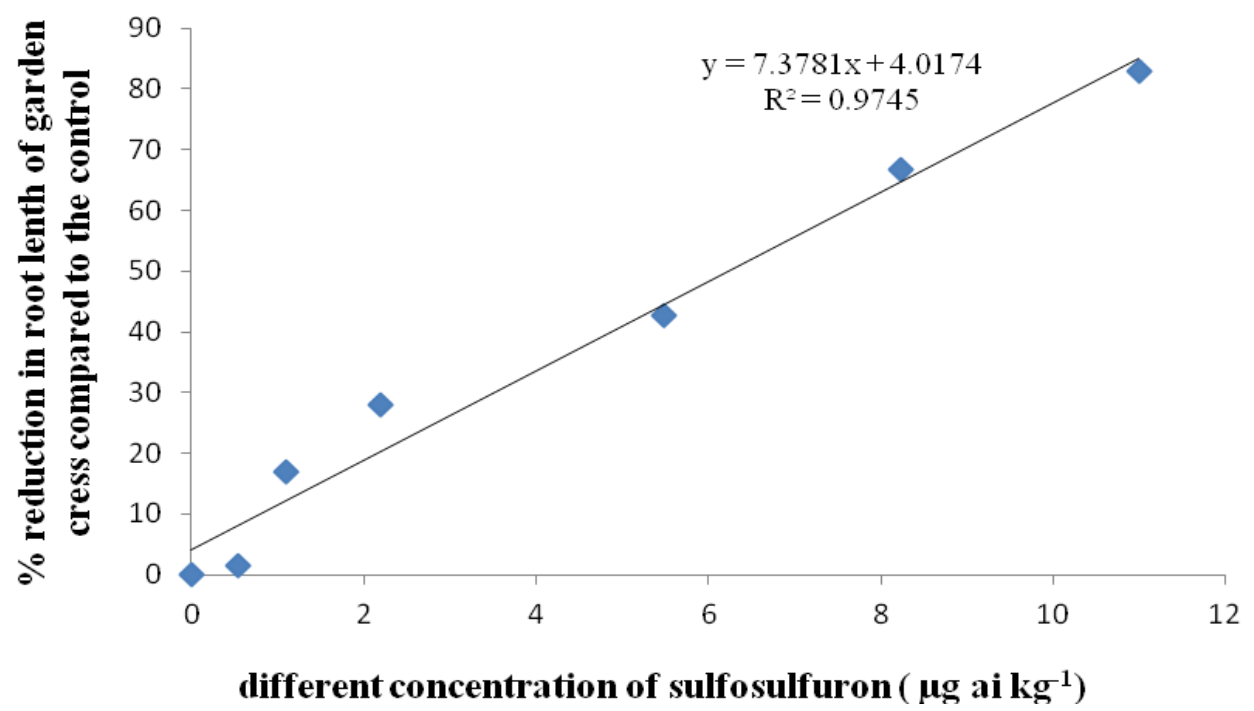

Figure 5. The percentage reduction in root length of garden cress plants versus different concentrations of sulfosulfuron ( $26.6 \mathrm{~g}$ a.i. $\mathrm{ha}^{-1}$ )

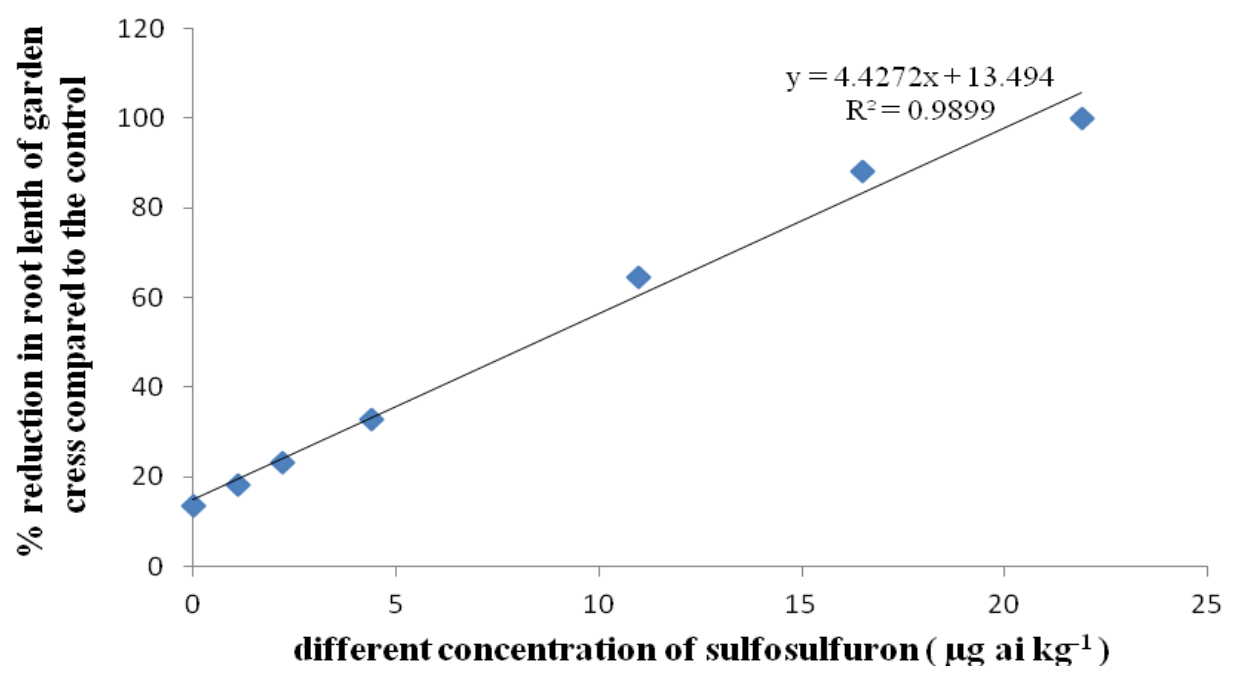

Figure 6. The percentage reduction in root length of garden cress plants versus different concentrations of sulfosulfuron ( $53.2 \mathrm{~g}$ a.i. $\mathrm{ha}^{-1}$ )

\section{Persistence of Sulfosulfuron in Wheat Field Soil}

\section{HPLC Method}

The results of extracted herbicide concentration in the soil for different rates are shown in Table 2. Results of the sulfosulfuron dissipation in the wheat field soil displayed that initial concentration of sulfosulfuron residues in the surface soil (0-10 $\mathrm{cm})$ were 9.8 and $10.1 \mu \mathrm{g}$ a.i. $\mathrm{kg}^{-1}$ for recommended rate $\left(26.6 \mathrm{~g}\right.$ a.i. ha $\left.{ }^{-1}\right)$ and 19 and $18.5 \mu \mathrm{g}$ a.i. $\mathrm{kg}^{-1}$ for double rate (53.2 $\mathrm{g}$ a.i. ha ${ }^{-1}$ ) application in 2014 and 2015, respectively. 3 days after application (DAA), dissipation of sulfosulfuron was 17.19 and $18.1 \%$ for $26.6 \mathrm{~g}$ a.i. $\mathrm{ha}^{-1}$ and 15.37 and $17.19 \%$ for $53.2 \mathrm{~g}$ a.i. $\mathrm{ha}^{-1}$ application in 2014 and 2015, respectively. 20 days after application, the residues decreased to 5.2 and 6.8 
$\mu \mathrm{g}$ a.i. $\mathrm{kg}^{-1}$ for recommended rate and 10.6 and $12.4 \mu \mathrm{g}$ a.i. $\mathrm{kg}^{-1}$ for double rate in 2014 and 2015, respectively. After 60 days of application, the residues decreased to 1.5 and $1.2 \mu \mathrm{g}$ a.i. $\mathrm{kg}^{-1}$ with 86.35 and $89.1 \%$ dissipation for recommended rate and 7.2 and 4.0 $\mu \mathrm{g}$ a.i. $\mathrm{kg}^{-1}$ with 67.24 and $81.8 \%$ dissipation for double rate in 2014 and 2015, respectively. 90 days after application, the sulfosulfuron residues were found to be below detectable level at recommended rate. However, 1.6 and $2.1 \mu \mathrm{g}$ a.i. $\mathrm{kg}^{-1}$ residues were detected at double rate in 2014 and 2015, respectively (Table 2). At recommended rate of application, the half-life of sulfosulfuron by the chemical extraction method were 17.28 and 19.42 days in 2014 and 2015, respectively.

Table 2. Persistence of sulfosulfuron residues in wheat field soil at the recommended (26.6 $\mathrm{g}$ a.i. $\mathrm{ha}^{-1}$ ) and double rates of application (53.2 $\mathrm{g}$ a.i. $\mathrm{ha}^{-1}$ ) by HPLC

\begin{tabular}{|c|c|c|c|}
\hline \multirow{2}{*}{ Time (days) } & \multirow{2}{*}{ year } & \multicolumn{2}{|c|}{ Herbicide residue remaining $\left( \pm\right.$ SD) $\left(\mu \mathrm{g} \text { a.i. } \mathrm{kg}^{-1}\right)^{\mathrm{a}}$} \\
\hline & & 26.6 g a.i. ha $^{-1}$ & 53.2 g a.i. $^{-1}$ \\
\hline \multirow[t]{2}{*}{0} & 2014 & $9.8( \pm 0.035)[10.82]$ & $19.0( \pm 0.065)[13.55]$ \\
\hline & 2015 & $10.1( \pm 0.030)[8.10]$ & $18.5( \pm 0.058)[15.83]$ \\
\hline \multirow[t]{2}{*}{3} & 2014 & $9.1( \pm 0.028)[17.19]$ & $18.6( \pm 0.074)[15.37]$ \\
\hline & 2015 & $9.0( \pm 0.024)[18.10]$ & $18.2( \pm 0.070)[17.19]$ \\
\hline \multirow[t]{2}{*}{10} & 2014 & $7.1( \pm 0.037)[35.39]$ & NA \\
\hline & 2015 & $7.5( \pm 0.041)[31.75]$ & $15.8( \pm 0.069)[28.11]$ \\
\hline \multirow[t]{2}{*}{20} & 2014 & $5.2( \pm 0.032)[52.68]$ & $10.6( \pm 0.054)[51.77]$ \\
\hline & 2015 & $6.8( \pm 0.029)[38.12]$ & $12.4( \pm 0.060)[43.58]$ \\
\hline \multirow[t]{2}{*}{30} & 2014 & $3.0( \pm 0.025)[72.70]$ & $8.7( \pm 0.061)[59.20]$ \\
\hline & 2015 & $2.0( \pm 0.033)[81.80]$ & $9.2( \pm 0.055)[63.40]$ \\
\hline \multirow[t]{2}{*}{60} & 2014 & $1.5( \pm 0.045)[86.35]$ & $7.2( \pm 0.078)[67.24]$ \\
\hline & 2015 & $1.2( \pm 0.040)[89.10]$ & $4.0( \pm 0.063)[81.80]$ \\
\hline \multirow[t]{2}{*}{90} & 2014 & BDL & $1.6( \pm 0.050)[92.72]$ \\
\hline & 2015 & BDL & $2.1( \pm 0.052)[90.44]$ \\
\hline \multirow[t]{2}{*}{125} & 2014 & BDL & BDL \\
\hline & 2015 & BDL & BDL \\
\hline
\end{tabular}

${ }^{\mathrm{a}}$ Average of three replicates; numbers in square brackets indicate $\%$ dissipation; NA=sample not analyzed; SD =standard deviation; BDL=below detectable level $\left(1 \mu \mathrm{g}\right.$ a.i. $\left.\mathrm{kg}^{-1}\right)$.

\section{Bioassay Method}

Data obtained in the study of sulfosulfuron persistence by the garden cress seed bioassay technique, calculated using the regression equation $\mathrm{Y}=7.3781 \mathrm{X}+4.0174$, indicated that the residues of sulfosulfuron were detected up to 90 DAA in 2014 and 2015 at the recommended rate of application (Table 3). At day 0, the decreases in garden cress root length were 78.3 and $80.4 \%$ for recommended rate and 82.17 and $79.2 \%$ for double rate in 2014 and 2015, respectively (Tables 3 and 4). At the recommended rate of application, the initial deposit of 10.06 and $10.35 \mu \mathrm{g}$ a.i. $\mathrm{kg}^{-1}$ in 2014 and 2015 decreased to 8.41 and $9.05 \mu \mathrm{g}$ a.i. $\mathrm{kg}^{-1}$ at 10 DAA in 2014 and 2015, respectively (Table 3 ). At the double rate of application, the initial deposit of 15.51 and $14.84 \mu \mathrm{g}$ a.i. $\mathrm{kg}^{-1}$ in 2014 and 2015 decreased to 12.44 and $12.76 \mu \mathrm{g}$ a.i. $\mathrm{kg}^{-1}$ at 10 DAA in 2014 and 2015, respectively (Table 4). 
Table 3. Persistence of sulfosulfuron residues at the recommended rate of application (26.6 g a.i. $\mathrm{ha}^{-1}$ ) by bioassay method

\begin{tabular}{|c|c|c|c|c|c|c|}
\hline \multirow[b]{2}{*}{ Days $^{\text {a }}$} & \multirow[b]{2}{*}{ Year } & \multicolumn{2}{|c|}{ Root length $\left( \pm\right.$ SD) $(\mathrm{cm})^{b}$} & \multirow[b]{2}{*}{$\begin{array}{c}\text { Root } \\
\text { inhibition } \\
(\%)\end{array}$} & \multirow[b]{2}{*}{$\begin{array}{c}\text { Average residue ( } \mu \mathrm{g} \\
\left.\text { a.i. } \mathrm{kg}^{-1}\right)\end{array}$} & \multirow[b]{2}{*}{$\begin{array}{c}\text { Dissipation } \\
(\%)\end{array}$} \\
\hline & & Untreated & Treated & & & \\
\hline \multirow{2}{*}{0} & 2014 & $13.8 \pm 1.3$ & $3.0 \pm 0.34$ & 78.3 & 10.06 & 8.46 \\
\hline & 2015 & $11.2 \pm 0.75$ & $2.2 \pm 1.0$ & 80.4 & 10.35 & 5.82 \\
\hline \multirow{2}{*}{3} & 2014 & $12.3 \pm 0.9$ & $2.9 \pm 0.8$ & 76.4 & 9.81 & 10.73 \\
\hline & 2015 & $12.3 \pm 1.1$ & $2.8 \pm 0.5$ & 77.3 & 9.93 & 9.64 \\
\hline \multirow{2}{*}{10} & 2014 & $11.5 \pm 0.7$ & $3.9 \pm 0.6$ & 66.1 & 8.41 & 23.47 \\
\hline & 2015 & $12.0 \pm 0.4$ & $3.5 \pm 1.0$ & 70.8 & 9.05 & 17.65 \\
\hline \multirow{2}{*}{20} & 2014 & $10.0 \pm 0.65$ & $4.8 \pm 0.75$ & 52.0 & 6.50 & 40.85 \\
\hline & 2015 & $11.1 \pm 0.9$ & $5.0 \pm 1.1$ & 54.9 & 6.89 & 37.30 \\
\hline \multirow{2}{*}{30} & 2014 & $10.8 \pm 0.9$ & $7.8 \pm 0.4$ & 27.8 & 3.22 & 70.70 \\
\hline & 2015 & $13.0 \pm 0.6$ & $8.8 \pm 1.0$ & 32.3 & 3.83 & 65.15 \\
\hline \multirow{2}{*}{60} & 2014 & $12.2 \pm 0.5$ & $9.6 \pm 0.8$ & 21.3 & 2.34 & 78.70 \\
\hline & 2015 & $10.8 \pm 0.8$ & $8.3 \pm 1.2$ & 23.4 & 2.62 & 76.16 \\
\hline \multirow{2}{*}{90} & 2014 & $11.0 \pm 1.3$ & $9.5 \pm 1.1$ & 13.6 & 1.29 & 88.26 \\
\hline & 2015 & $12.4 \pm 1.0$ & $10.1 \pm 0.7$ & 18.5 & 1.96 & 82.16 \\
\hline \multirow{2}{*}{125} & 2014 & $12.6 \pm 1.2$ & $12.9 \pm 0.25$ & 0 & BDL & 100 \\
\hline & 2015 & $12.0 \pm 0.5$ & $12.2 \pm 0.5$ & 0 & BDL & 100 \\
\hline
\end{tabular}

${ }^{\mathrm{a}}$ Day after herbicide application.

${ }^{\mathrm{b}}$ Average of four replicates root length for 20 plants.

$\mathrm{SD}=$ standard deviation

$\mathrm{BDL}=$ below detectable level $\left(1 \mu \mathrm{g}\right.$ a.i. $\left.\mathrm{kg}^{-1}\right)$.

Table 4. Persistence of sulfosulfuron residues at the double rate of application (53.2 $\mathrm{g}$ a.i. $h \mathrm{a}^{-1}$ ) by bioassay method

\begin{tabular}{|c|c|c|c|c|c|c|}
\hline \multirow[b]{2}{*}{ Days $^{a}$} & \multirow[b]{2}{*}{ Year } & \multicolumn{2}{|c|}{ Root length $\left( \pm\right.$ SD) $(\mathrm{cm})^{b}$} & \multirow[b]{2}{*}{$\begin{array}{l}\text { Root } \\
\text { inhibition } \\
(\%)\end{array}$} & \multirow[b]{2}{*}{$\begin{array}{l}\text { Average residue ( } \mu \mathrm{g} \\
\text { a.i. } \mathrm{kg}^{-1} \text { ) }\end{array}$} & \multirow[b]{2}{*}{$\begin{array}{l}\text { Dissipation } \\
(\%)\end{array}$} \\
\hline & & Untreated & Treated & & & \\
\hline \multirow{2}{*}{0} & 2014 & $12.9 \pm 0.67$ & $2.3 \pm 0.34$ & 82.17 & 15.51 & 29.43 \\
\hline & 2015 & $12.5 \pm 1.3$ & $2.6 \pm 0.6$ & 79.2 & 14.84 & 32.48 \\
\hline \multirow{2}{*}{3} & 2014 & $12.3 \pm 0.48$ & $2.7 \pm 0.58$ & 78.04 & 14.57 & 33.71 \\
\hline & 2015 & $11.8 \pm 0.75$ & $2.8 \pm 0.3$ & 76.27 & 14.17 & 35.53 \\
\hline \multirow{2}{*}{10} & 2014 & $10.5 \pm 1.2$ & $3.3 \pm 0.54$ & 68.58 & 12.44 & 43.40 \\
\hline & 2015 & $11.0 \pm 1.0$ & $3.3 \pm 0.4$ & 70.0 & 12.76 & 41.94 \\
\hline \multirow{2}{*}{20} & 2014 & $11.0 \pm 0.25$ & $5.0 \pm 0.75$ & 54.5 & 9.26 & 57.87 \\
\hline & 2015 & $11.2 \pm 1.1$ & $4.9 \pm 0.64$ & 56.25 & 9.65 & 56.09 \\
\hline \multirow{2}{*}{30} & 2014 & $10.8 \pm 0.9$ & $6.2 \pm 0.4$ & 42.59 & 6.57 & 70.10 \\
\hline & 2015 & $9.5 \pm 1.2$ & $5.1 \pm 0.54$ & 46.3 & 7.41 & 66.28 \\
\hline \multirow{2}{*}{60} & 2014 & $11.2 \pm 0.45$ & $8.0 \pm 0.45$ & 28.57 & 3.40 & 84.53 \\
\hline & 2015 & $10.4 \pm 0.5$ & $7.1 \pm 0.3$ & 31.73 & 4.11 & 81.30 \\
\hline \multirow{2}{*}{90} & 2014 & $11.2 \pm 1.1$ & $8.8 \pm 0.65$ & 21.4 & 1.78 & 91.90 \\
\hline & 2015 & $11.0 \pm 1.0$ & $8.4 \pm 1.1$ & 23.63 & 2.28 & 89.60 \\
\hline \multirow{2}{*}{125} & 2014 & $11.0 \pm 0.7$ & $11.2 \pm 0.3$ & 0 & BDL & 100 \\
\hline & 2015 & $12.2 \pm 0.8$ & $12.4 \pm 0.4$ & 0 & BDL & 100 \\
\hline
\end{tabular}

${ }^{a}$ Day after herbicide application.

${ }^{\mathrm{b}}$ Average of four replicates root length for 20 plants.

$\mathrm{SD}=$ standard deviation

BDL $=$ below detectable level $\left(1 \mu \mathrm{g}\right.$ a.i. $\left.\mathrm{kg}^{-1}\right)$. 
In 2015, the residues of sulfosulfuron dissipated with a slow rate so that the residues were detected up to $90 \mathrm{DAA}$ at the recommended rate of application whereas the residues were below detectable level at 125 DAA (Table 3). Moreover, the residues were detected up to $90 \mathrm{DAA}$ at the double rate in both years (Table 4). At the recommended rate of application, Fitting data of the percentage dissipation of herbicide at different intervals to a three -parameter sigmoidal model indicated that $\mathrm{X}_{0}$ value, which is the half-life of herbicide and estimated based on the percentage of sulfosulfuron dissipation versus different day intervals, were found to be 20.31 days in 2014 and 21.78 days in 2015 by the bioassay method (Table 5).

Table 5. The three-parameter sigmoidal model $f=\left(a /\left(1+\exp \left(-\left(x-x_{0}\right) / b\right)\right)\right.$ to determine dissipation time (DT 50) of sulfosulfuron herbicide at the recommended rate of application (26.6 $\mathrm{g}$ a.i. $\left.\mathrm{ha}^{-1}\right)$ by bioassay and HPLC techniques

\begin{tabular}{|c|c|c|c|c|}
\hline \multirow{3}{*}{$\begin{array}{l}\text { Model } \\
\text { parameters }\end{array}$} & \multicolumn{4}{|l|}{ Technique } \\
\hline & \multicolumn{2}{|l|}{ Bioassay } & \multicolumn{2}{|l|}{ HPLC } \\
\hline & 2014 & 2015 & 2014 & 2015 \\
\hline $\mathrm{A}$ & $89.87(0.801)$ & $86.85(0.920)$ & $94.00(0.99)$ & $96.55(0.94)$ \\
\hline B & $8.97(0.290)$ & $8.62(0.321)$ & $10.20(0.29)$ & $9.44(0.23)$ \\
\hline $\mathrm{X}_{0}$ & $20.31(0.396)$ & $21.78(0.450)$ & $17.28(01.02)$ & $19.42(01.21)$ \\
\hline $\mathrm{R}^{2}$ & 0.97 & 0.96 & 0.98 & 0.96 \\
\hline RMSE & 9.21 & 7.71 & 5.30 & 8.95 \\
\hline P-value & $<0.0001$ & $<0.0001$ & $<0.0001$ & $<0.0001$ \\
\hline
\end{tabular}

Values in parentheses indicate $\pm \mathrm{SE}$ (standard error).

$\mathrm{A}=$ maximum dissipation of herbicide.

$\mathrm{B}=$ the slope of the curve around the $\mathrm{X}_{0}$.

$\mathrm{X}_{0}=$ is time required for $50 \%$ dissipation.

\section{Discussion}

\section{Bioassay Analysis of Soil-Bound Herbicides}

According to the bioassay experiment, root parameter was more sensitive to sulfosulfuron as compared with shoot. A root length inhibition bioassay is an effective tool to detect small amounts of phytotoxic compounds in the soil, however it may not necessarily reflect yields observed in field. Several bioassays have been developed for the detection of soil residual herbicides. A bioassay involves assessing some component of plant growth such as root length, shoot length, or yield as a function of herbicide concentrations in soil. A bioassay can be used as a quantitative procedure to determine the total amount of a certain herbicide residue present in a soil sample or to assess phytotoxicity (Sunderland et al., 1991). The application of bioassays to measure ALS inhibiting herbicides in the soil is an effective method as these compounds are potent inhibitors of root and shoot growth of susceptible plants (Brown, 1990). This method has proven useful and valid for the detection of several different herbicide residues (Szmigielska et al., 1998; Sunderland et al., 1991).

\section{Comparison of Sulfosulfuron Persistence in Field Soil By HPLC and Bioassay Methods}

At the recommended rate of application (26.6 $\mathrm{g}$ a.i. $\mathrm{ha}^{-1}$ ), the initial deposit observed on day 0 was 10.06 and $10.35 \mu \mathrm{g}$ a.i. $\mathrm{kg}^{-1}$ by the bioassay in 2014 and 2015 versus 9.8 and $10.1 \mu \mathrm{g}$ a.i. $\mathrm{kg}^{-1}$ by HPLC in 2014 and 2015, respectively. The differences between 
residues detected by the two techniques were more obvious with time, so that on 3 DAA for recommended rate the residues detected by HPLC was 9.1 and $9.0 \mu \mathrm{g}$ a.i. $\mathrm{kg}^{-1}$ in 2014 and 2015 versus 9.81 and $9.93 \mu \mathrm{g}$ a.i. $\mathrm{kg}^{-1}$ detected by bioassay in 2014 and 2015, respectively. The dissipation rate of residues estimated by HPLC was more than bioassay. On 20 DAA for recommended rate, dissipation of herbicide was 40.85 and $37.30 \%$ by bioassay technique, in 2014 and 2015 versus 52.68 and $38.12 \%$ by HPLC technique in 2014 and 2015, respectively. At the recommended rate of application, sulfosulfuron residues were detected up to 60 days after treatment by HPLC method in both years, whereas residues were detected up to 90 days after treatment by bioassay method in 2014 and 2015. It has demonstrated that the herbicide residues are adsorbed tightly to soil particles with time, consequently the extraction technique is inadequate for detecting the residues. In contrast, the bound residues of herbicide can be released from the soil matrix during plant growth and thus the bioassay technique is more sensitive technique than HPLC and can detect more residues (Paul et al., 2009). The major advantage of the bioassay over the HPLC is, its relative simplicity. The HPLC assay is moderately labor-intensive and requires expensive equipment whereas the bioassay is easy to perform and requires no special equipment. According to Ranft et al. (2010), the chemical extraction measures the concentration of herbicide, but not the rate influencing the crop, while the bioassay method measures amount of herbicide available to the plant, but not unavailable active herbicide in the soil.

Our study highlighted that the estimated half-life of herbicide by HPLC was lower than that of bioassay (Table 5). At the recommended rate of application (26.6 $\mathrm{g}$ a.i. $\mathrm{ha}^{-1}$ ), estimated half-life of herbicide by bioassay and HPLC were 20.31 and 17.28 days in 2014 and 21.78 and 19.42 days in 2015, respectively. In a study by Paul et al. (2009), the half-lives of metsulfuron-methyl by HPLC and bioassay were found to be 6.3-7.8 and 17.5 days, respectively. The ability of a soil residual herbicide to have a phytotoxic effect on a sensitive crop depends on the half-life of the herbicide being used. The halflife of herbicides in soil varies with the chemical structure and soil conditions that affect degradation. According to Sarmah et al. (1999), the half-life of a sulfonylurea herbicide in soil can vary significantly depending on $\mathrm{pH}$, temperature, moisture, texture and organic matter content of the soil (Blacklow and Pheloung, 1991; Sarmah et al., 1999). Sulfosulfuron, with a field half-life of 14 to 75 days, is often one of the more persistent herbicides (Vencill, 2002).

According to the bioassay and HPLC results, at two rates of application (26.6 and $53.2 \mathrm{~g}$ a.i. $\mathrm{ha}^{-1}$ ), Sulfosulfuron residues decreased with time in 2014 and 2015. This may be due to various causes. Once a herbicide is applied, there are eight possible routes that may affect its dissipation: 1 . adsorption to clay and organic matter, 2. leaching with the downward percolation of water, 3. volatilization to the atmosphere, 4.uptake by plants and/or soil organisms, 5. movement with runoff water or eroded soil, 6. microbial degradation, 7. chemical degradation, and 8. photolysis (McEwen and Stephenson, 1979). These processes are affected by the adsorption of a herbicide to soil colloids and soil organic matter. The greater the adsorption of a herbicide to a particular soil, the less the losses from leaching and volatilization (Smith, 1982). Depending on the chemical nature of the herbicide the importance of each of these routes can be quite different. One of the properties of some ALS inhibiting herbicides such as Sulfosulfuron, is soil residual activity that can result in weed control throughout the growing season. However, this characteristic can also cause crop damage and an economic loss due to a phytotoxic effect on sensitive rotational crops (O'Sullivan et al., 1998). The degree to 
which a residual herbicide can persist and cause damage is influenced by three factors including soil properties, environmental conditions and landscape position (Moyer and Hamman, 2001; Schoenau et al., 2005).

According to the bioassay and HPLC results, at two rates of application, Sulfosulfuron had different soil persistence in 2014 and 2015. This may be due to various environmental conditions. The environment has a large influence on herbicide residue persistence. Many herbicides that have residual activity are degraded in soil by hydrolysis and/or microbial degradation (Beckie and McKercher, 1989; Vencill, 2002). The relative importance of microbial degradation as compared to chemical hydrolysis is dependant on many factors. Joshi et al. (1985) found that a sulfonylurea herbicide degraded faster in acidic soils because both forms of degradation took place. In alkaline soils however, microbial degradation was the primary source of degradation, resulting in a slower rate of dissipation. Temperature and soil moisture levels have a significant effect on soil microbial populations and activity. Beckie and McKercher (1989) found that lower temperatures and drier soils resulted in the ability to detect herbicide residues with a bioassay for a longer time period after application. Experimental sites, which received a higher level of precipitation, had lower amounts of phytotoxic residues of sulfonylurea herbicides present the year after application (Shinn et al., 1998). Hill et al. (1998) found that yearly precipitation levels had a significant effect on the persistence of quinclorac, with drier conditions increasing the soil residual half-life of the herbicide. This suggests that in years of lower than average growing season temperatures and/or lower precipitation, residual herbicides may persist longer in the soil. This can have negative effects on sensitive rotational crop species, resulting in reduced yield and/or later maturing crops.

\section{Conclusion}

In this study, the reliability and accuracy of HPLC and bioassay methods were evaluated to detect sulfosulfuron residues at macro quantitative levels. Results revealed that the bioassay was more sensitive than HPLC for the determination of sulfosulfuron residues. According to the bioassay experiment, root parameter was more sensitive to sulfosulfuron as compared with the shoot. Root length inhibition bioassay was a useful tool to detect small amounts of sulfosulfuron residues in the soil. So the residues of sulfosulfuron herbicide were detected up to 60 and 90 days after application by HPLC and bioassay techniques, respectively. These findings can be applicable for agriculture since knowledge on the degradation rates of herbicides usage, and their possible effects on sensitive rotational crops can help for making effective management decisions. Further studies need to be carried out for a better understanding of the sulfosulfuron behavior in different soil and meteorological conditions.

\section{REFERENCES}

[1] Alonso-Prados, L. J., Hernandez-Sevillano, E., Llanos, S., Villarroya, M., Garcia-Baudin, J. M. (2002): Effects of sulfosulfuron soil residues on barley (Hordeum vulgare), sunflower (Helianthus annuus) and common vetch (Vicia sativa). - Crop Protection 21: 1061-1066. 
[2] Beyer, E. M., Duffy, M. J., Hay, J. V., Schlueter, D. D. (1988): Sulfonylureas. - In: Kearney, P. C., Kaufman, D. D. (Eds.) Herbicides chemistry, degradation and mode of action. Vol. 3, Pp. 117-189. Marce Dekker, New York.

[3] Beckie, H. J., McKercher, R. B. (1989): Soil residual properties of DPX-A7881 under laboratory conditions. - Weed Science 37(3): 412-418.

[4] Blacklow, W. M., Pheloung, P. C. (1991): Sulfonylurea herbicides applied to acidic sandy soils: a bioassay for residues and factors affecting recoveries. - Australian Journal of Agricultural Research 42: 1205-1216.

[5] Brown, H. M. (1990): Mode of action crop selectivity and soil relations of the sulfonylurea herbicides. - Journal of Pesticide Science 29: 263-281.

[6] Coly, A., Aaron, J. J. (1999): Photochemically-induced fluorescence determination of sulfonylurea herbicides using micellar media. - Talanta 49: 107-117.

[7] Derksen, D. A., Anderson, R. L., Blackshaw, R. E, Maxwell, B. (2002): Weed dynamics and management strategies for cropping systems in the Northern Great Plains. Agronomy Journal 94: 174-185.

[8] Faheed, F. A., Abd-Elfattah, Z. (2007): Alteration in growth and physiological activities in Chlorella vulgaris under the effect of photosynthetic inhibitor diuron. - International Journal of Agriculture and Biology 9: 631-634.

[9] Ferris, I. G., Haigh, B. M. (1992): Prediction of herbicide persistence and phytotoxicity of residues. - Proceedings First International Weed Control Congress, Melbourne 1:193207.

[10] Guibiao, Y., Wei, Z., Xin, C., Canping, P., Shuren, J. (2006): Determination and quantitation of Ten Sulfonylurea herbicides in soil samples using liquid chromatography with electrospray ionization mass spectrometric detection. - Chinese Journal of Analytical Chemistry 34: 1207-1212.

[11] Gunther, P., Pestemer, W., Rahman, A., Nordmeyer, H. (1993): A bioassay technique to study the leaching behavior of sulfonylurea herbicides in different soils. -Weed Research 33: 177-185.

[12] Haney, R. L., Senseman, S. A., Hons, F. M., Zuberer, D. A. (2000): Effect of glyphosate on soil microbial activity and biomass. - Weed Science 48: 89-93.

[13] Hasanuzzaman, M., Ali, M. H., Alam, M. M., Akther, M., Alam, K. F. (2009): Evaluation of Preemergence Herbicide and Hand Weeding on the Weed Control Efficiency and Performance of Transplanted Aus Rice. - American-Eurasian Journal of Agronomy 2(3): 138-143.

[14] Hernandez-Sevillano, E., Villarroya, M., Alonso-Prados, J. L., Garca-Baudn, J. M. (2001): Bioassay to detect sulfosulfuron and triasulfuron residues in soil. - Weed Technology15: 447-452.

[15] Hill, B. D., Moyer, J. R., Inaba, D. J., Doram, R. (1998): Effect of moisture on quinclorac dissipation in Lethbridge soil. - Canadian Journal of Plant Science 78: 697-702.

[16] Johnson, E. N., Moyer, J. R., Thomas, A. G., Leeson, J. Y., Holm, F. A., Sapsford, K. L., Schoenau, J. J., Szmigielski, A. M., Hall, L. M., Kuchuran, M. E., Hornford, R. G. (2005): Do repeated applications of residual herbicides result in herbicide stacking? - In: van Acker, R. C. (ed.) Soil Residual Herbicides: Science and Management (Vol. 3., pp. 53-70). Canadian Weed Science Society - Societe canadienne de malherbologie. SainteAnne-de Bellevue, Quebec.

[17] Joshi, M. M., Brown, H. M., Romesser, J. A. (1985): Degradation of chlorsulfuron by soil microorganisms. - Weed Science 33: 888-893.

[18] Maheshwari, S. T., Ramesh, A. (2007): Adsorption and degradation of sulfosulfuron in soils. - Environmental Monitoring and Assessment 127: 97103.

[19] McEwen, F. L., Stephenson, G. R. (1979): The Use and Significance of Pesticides in the Environrnent. - John Wiley and Sons, Toronto. 
[20] Menne, H. J., Berger, B. M. (2001): Influence of straw management nitrogen fertilization and dosage rates on the dissipation of five sulfonylureas in soil. - Weed Research 41: 229-453.

[21] Moyer, J. R., Hamman, W. M. (2001): Factors affecting the toxicity of MON 37500 residues to following crops. - Weed Technology 15(1): 42-47.

[22] Nurse, R. E., Hamill, A. S., Swanton, C. J., Tardif, F. J., Sikkema, P. H. (2007): Weed control and yield response to sulfosulfuron in wheat. - Weed Technology 21:453-45.

[23] Nystrom, B., Blanck, H. (1998): Effects of the sulfonylurea herbicide metsulfuron methyl on growth and macromolecular synthesis in the green alga Selenastrum capricornutum. Aquatic Toxicology 43: 25-39.

[24] O'Sullivan, J., Thomas, R. J., Bouw, W. J. (1998): Effect of imazethapyr and imazamox soil residues on several vegetable crops grown in Ontario. - Canadian Journal of Plant Science 78: 647-651.

[25] Parrish, S. K., Kaufman, J. E., Croon, K. A., Ishida, Y., Ohta, K., Ioth, S. (1995): MON 37500: A new selective herbicide to control annual and perennial weeds in wheat. Brighton Crop Protection Conference - Weeds 3: 1127 -1132.

[26] Paul, R., Sharma, R., Kulshrestha, G., Singh, S. B. (2009): Analysis of metsulfuronmethyl residues in wheat field soil: a comparison of HPLC and bioassay techniques. Pest Management Science 65:963-968.

[27] Pusino, A., Fiori, M. G., Braschi, I., Gessa, C. (2003): Adsorption and desorption of triasulfuron by soil. - Journal of Agricultural and Food Chemistry 51(18): 5350 -5354.

[28] Rahman, M., Soomro, U. A., Zahoor-ul-Haq, M., Gul, S. (2008): Effects of NaCl Salinity on Wheat (Triticum aestivum L.) Cultivars. - World Journal of Agricultural Sciences 4(3): 398-403.

[29] Ranft, R. D., Seefeldt, S. S., Zhang, M., Barnes, D. L. (2010): Development of a Soil Bioassay for Triclopyr Residues and Comparison with a Laboratory Extraction. -Weed Technology 24:538-543.

[30] Saha, S., Kulshrestha, G. (2002): Degradation of sulfosulfuron, a sulfonylurea herbicide, as influened by abiotic factors. - Journal of Agricultural and Food Chemistry 50(16): 45724575.

[31] Saha, S., Singh, S. B., Kulshrestha, G. (2003): High performance liquid chromatographic methods for residue determination of sulfosulfuron. - Journal of Environmental Science and Health, Part B 38(3):337-347.

[32] Sarmah, A. K., Kookana, R. S., Alston, A. M. (1998): Fate and behavior of the three sulfonylurea herbicides such as triasulfuron, metsulfuron-methyl and chlorsulfuron in Australian soil environment. - Australian Journal of Agricultural Research 49: 775790.

[33] Sarmah, A. K., Kookana, R. S., Alston, A. M. (1999): Degradation of chlorsulfuron and triasulfuron in alkaline soils under laboratory conditions. - Weed Research 39:83-94.

[34] Schoenau, J. J., Szmigielski, A. M., Eliason, R. C. (2005): The effect of landscape position on residual herbicide activity in prairie soils. - In: Van Acker, R. C. (ed.) Soil Residual Herbicides: Science and Management. Topics in Canadian Weed Science (Vol. 3., pp. 45-52). Canadian Weed Science Society - Société canadian de malherbologie. Sainte-Anne-de Bellevue, Québec.

[35] Shinn, S. L., Thill, D. C., Price, W. J., Ball, D. A. (1998): Response of downy brome (Bromus tectorum) and rotational crops to MON-37500. - Weed Technology 12: 690698.

[36] Smith, A. E. (1982): Herbicides and the soil environment in Canada. - Canadian Journal of Soil Science 62(33): 433-460.

[37] Stork, P. (1995): Field leaching and degradation of soil applied herbicides in a gradationally textured alkaline soil: chlorsulfuron and triasulfuron. - Australian Journal of Agricultural Research 46: 1445-1458.

[38] Stork, P., Hannah, M. C. (1996): A bioassay method for formulation testing and residue studies of sulfonylurea and sulfonanylide herbicides. - Weed Research 36: 271-281. 
[39] Sunderland, S. L., Santelmann, P. W., Boughman, T. A. (1991): A rapid, sensitive soil bioassay for sulfonylurea herbicides. - Weed science 39: 296-298.

[40] Szmigielska, A. M., Schoenau, J. J., Greer, K. (1998): Comparison of chemical extraction and bioassay for measurement of metsulfuron in soil. - Weed science 46: 487-493.

[41] Szmigielski, A. M., Schoenau, J. J., Irvine, A., Schilling, B. (2008): Evaluating a mustard root-length bioassay for predicting crop injury from soil residual Flucarbazone. Communication in Soil Science and Plant Analysis 39: 413-420.

[42] Szmigielski, A. M., Schoenau, J. J., Johnson, E. N., Holm, F. A., Sapsford, K. L., Liu, J. (2009): Development of a laboratory bioassay and effect of soil properties on sulfentrazone phytotoxicity in Soil. - Weed Technology 23: 486-491.

[43] Tchan, Y. T., Roseby, E. J., Funnell, G. R. (1975): A new rapid specific bioassay method for photosynthesis inhibiting herbicides. -Soil Biology and Biochemistry 7: 39-77.

[44] Vahedi-Sheikhhasan, M. R., Mirshekari, B., Farahvash, F. (2012): Weed Control in Wheat Fields by Limited Dose of Post-Emergence Herbicide. - World Applied Sciences Journal 16(9): 1243-1246.

[45] Vencill, W. K. (ed.) (2002): Herbicide Handbook (8th ed.). - Weed Science Society of America, Lawrence, USA.

[46] Watson, P. R., Checkel, S. (2005): Soil residual herbicide bioassays: science and practice. - In: Van Acker R. C. Soil Residual Herbicides: Science and Management (Vol. 3., pp. 71-79). Canadian Weed Science Society - Societe canadienne de malherbologie. SainteAnne-de Bellevue, Quebec.

[47] Ye, Q. F., Sun, J. H., Wu, J. M. (2003): Cause of phytotoxicity of metsulfuron-methyl bound residues in soil. - Environmental Pollution 126: 417-423. 